\title{
Youth ministry as an agency of youth development for the vulnerable youth of the Cape Flats
}

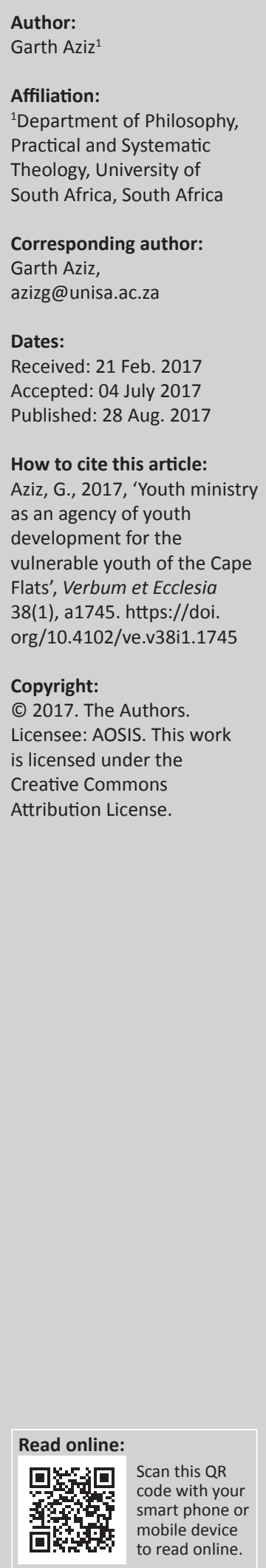

Religiosity has a profound role and influence on youth development within a community. Religiosity promotes risk reduction and positive moral characteristics and thus remains an avenue of opportunity for transformation in considering the lived experiences of vulnerable young people living on the Cape Flats in the Western Cape, South Africa. The Cape Flats is an area that is overwhelmed with unemployment, poverty, gang violence, chemical substance abuse and a general societal abandonment of young people. It is out of dire hopelessness that a meaningful relationship with God can be experienced by youth. The Cape Flats is, therefore, a fertile space for an intervention of religiosity. This article will research how the agency of youth ministry as a positive youth development can assist in youth development within a community in tension like that of the Cape Flats. While youth development is a broad category for consideration and research, this article will primarily focus on identity formation of young people, in particular, the vulnerable youth living on the Cape Flats.

Intradisciplinary and/or interdisciplinary implications: The agency of youth ministry, in an evangelical epistemology, should seek to address the influencers on adolescent identity formation, as one's identity has a direct bearing on faith formation. The potential outcome of the article would allow the youth ministry to take serious the impact of the lived realities of youth and adjust their programmatic designs and outcomes, in relation to youth faith formation.

\section{Introduction}

The coloured ${ }^{1}$ adolescent ${ }^{2}$ living on the Cape Flats, a concept and place introduced and enforced by the apartheid government of South Africa, is adversely affected by many negative influences. The Cape Flats, a community in tension, imposes daily confrontations and often life-threatening experiences on young persons with varying degrees of violence, unemployment of self and family and a general lack of well-being to their welfare. The young person on the Cape Flats is regarded as vulnerable as these negative experiences, which have become a part of the daily lives of young people living on the Cape Flats, could have wide-ranging effects on the development of the young person.

The article argues that Christian religiosity - faith formation - coordinated and facilitated through the agency of the youth ministry as a resource for positive youth development (PYD), can have a positive influence on the identity formation of the young person living in communities in tension. By proposing that the youth ministry can serve as an agent of PYD, this article will address some aspects of youth development by reflecting on the historical setting of the Cape Flats during South African apartheid history, and the lived realities of contemporary youth on the Cape Flats, which can be described as a community in tension. The aim of the article, ultimately, is to propose that the youth ministry through Christian religiosity can serve as PYD and contribute to PYD by focussing specifically on the identity formation of the young person. The article attempts to address the research problem of identity formation of the coloured youth living on the Cape Flats by asking the following question: How can the agency of youth ministry facilitate a positive development in young people living on the Cape Flats whose lives are continually being threatened by self and context?

\footnotetext{
1.The author acknowledges the sensitivity around the term 'coloured' in racial and identity politics as opposed to the more accepted term of 'mixed race'. The author intentionally uses the terms 'coloured' as it is more applicable in the contextual setting of the article. The author also uses the terms as his major dialogue partner in the article, Muhammed Adhikari $(2005,2008,2009)$, utilises the terms in his academic works and is, therefore, a suitable categorisation or identification of a people's grouping. The author will expand on the concept of coloured further on in the article.

2.Adolescence is a fluid concept where age no longer serves as markers for the beginning or end of adolescence, instead, adolescence starts with puberty and ends with individuation (Strong 2014:1). Yet, it will be prudent to reflect an age that is used in a South African context as defined by the National Youth Development Agency Act of South Africa (2008:11), which marks adolescence between 14 context as defined by the National Youth Development Agency Act of South Africa (2008:11), which marks adolescence between 14
years old and 35 years old. When referring to adolescence or youth, however, the author is using it inclusive of children, youth and young adults (cf. Nel 2000:8). Furthermore, Counted (2016:1) sees adolescents as 'a community in transition awaiting God who reveals Himself within their ontological crisis and experiences'. In this sense, adolescence is a hermeneutical journey where God is revealed and experienced in the lived experiences of youth.
} 


\section{Research problem}

The coloured identity in the South African context has always been a contentious matter. The subject of the coloured identity has experienced historical and contemporary marginalisation arguably because of not having a nationally recognisable culture or identity, and this, in turn, has caused much tension among the coloured community, raising questions as to what really is a coloured. The coloured adolescent living on the Cape Flats, therefore, is in need of intervention to assist with identity formation as this has a direct bearing on their faith formation journey.

\section{Setting the context}

Müller (2004:304) argues that any practical theological research has to begin in a local setting or context before it can be generalised to a broader context. Defining context will always be subjective as it has a local and global expression. My contention is that before any theory can be globalised, it has to be situated in a local context; however, it then has to find a global expression and application in order to 'deconstruct negative discourses' (Müller 2004:304). The beginning of theory is therefore contextual. The local context in this specific situation takes into consideration the coloured adolescent growing up on the Cape Flats in the Western Cape. The Cape Flats predominantly comprise the coloured and black communities (Bray et al. 2012:27). My interest in this subject is because the Cape Flats is my place of birth and hometown. A second interest in this particular context is because of me being classified as a coloured in a South African context. It is a context of extreme tensions filled with existential questions regarding our place in South African society. The majority of the coloured lived experience is characterised by rejection, systemic and structural violence and abject poverty (Bray et al. 2012:99). In this first section, therefore, the author will briefly address and develop the concepts of the coloured adolescent and the lived experiences on the Cape Flats as they inform the context addressed in this article.

\section{The coloured adolescent}

Coloureds, according to identity politics, is an ethnic and social grouping of people from mixed race origin, which has its history as part of the slave trade, and the indigenous Khoisan peoples of Africa (Adhikari 2005:2; Amoateng \& Richter 2007:2; Calix 2013:48). Some might even hold to the theory of miscegenation where coloureds are a created group because of interracial sexual relations between the white slave owner and the black slave (Adhikari 2008). In fact, being coloured as an identity or an ethnic group is a choice as not all 'coloureds' ${ }^{3}$ accept the classification because of a rejectionist politic as a response to an oppressive apartheid government (Adhikari 2005:XV). Colouredness ${ }^{4}$ is not a

3.The author utilises a lower case in this instance as it denotes a rejectionist politic of those classified politically as coloured but rejected by the individual. One especially saw a rejectionist politic during the peak days of apartheid.

4.Colouredness in a sense is an expression of being coloured. It is manifested and expressed in various manners, influenced by one's age, gender, language, religion, geographic location and even life experience. The concept of coloured is more than geographic location and even life experience. The concept of coloured is more than
just a race; it is also a cultural identity. Colouredness as an expression of being coloured, therefore, can never be homogenous. homogenous group. If one removes colouredness as an identity in a context where identity politics is rife, and where one is identified by a cultural or racial description, what is there to help a 'coloured' youth develop an identity as a South African? This is recently evidenced in the national discussion around the gold medal Olympian Wayde van Niekerk at the Rio 2016 Olympics as to whether it is a victory for South Africa or for the coloured community, where colouredness was once again dismissed as a non-issue as there does not exist a coloured ethnic grouping except that all are black (Bernardo 2016). This racial and ethnic distinction, however, is evidenced in the categorisation when applying at institutions where there remain tickboxes for the different racial and ethnic groupings in South Africa, of which coloured is one (Bray et al. 2012:23). One has to take cognisance of the internalisation by many coloureds as not being white enough nor black enough and continues to symbolise a rejection by the apartheid and the post-apartheid governments in South African history (Adhikari 2009:xv-xvi; McKaiser 2012). The history of the coloured identity was always a negative one. Brittian et al. (2013) maintain:

that it is important to know where you have come from in order to know where you are going, and this sentiment was also echoed by youth in our study. (p. 654)

Although Nel and Thesnaar (2006:94) argue that identity has taken on a different expression post-1994 in South Africa, one's identity is, however, contingent on one's broader social context (Noble-Carr \& Woodman 2016:3), which would include one's history.

\section{The Cape Flats: A community in tension}

The daily struggle experienced by coloureds is no more vividly evidenced in the structural setting of the Cape Flats. The Cape Flats in the Western Cape is an area of stark contrasts. It is home to affluent and self-sustaining communities as well as communities, known as townships, which are plagued with poverty, crime, chemical substance abuse and high unemployment. It was recently published that the Western Cape is the second largest province in South Africa with recorded murders, of which 7 of the 10 highest places with recorded murders are from the Cape Flats, of which all are townships (ENCA 2016). Bowers Du Toit (2014) goes to great lengths to describe the level of crime and violence on the Cape Flats, as it is held at siege by gangsterism, which threatens and, yet ironically, protects communities.

Historically, the Cape Flats has its origins in the apartheid era of South Africa, where the local black and coloured citizens, through the Group Areas Act of 1950, were forcibly removed from their places of residences and relocated to townships at the edges of the city centre. The Cape Flats can be described as a sort of wasteland (Bowers Du Toit 2014:1), characterised by overcrowding and poor housing conditions, high unemployment, broken and dysfunctional family settings, chemical substance abuse and systemic violence (Dames 2008:89). Furthermore, there seems to be a general apathy from the youth on the Cape Flats as evidenced through their high involvement in gang violence in the townships (Bowers Du Toit 2014:2), 
and the problem of teenage pregnancy (IOL 2015). The lived realities on the Cape Flats pose a dire threat to the well-being and identity of the young person.

The Cape Flats could be argued to be a community in tension. Parker, Wills and Wills (2008:4-5) argue that a community in tension occurs as a result of various factors or tensions that exist simultaneously that threaten the well-being of the citizens of that particular community, yet ironically, those tensions are also what hold the community together. What makes young people more susceptible to a struggling process of identity formation is because of a lack of identification with a group of people communally, particularly significant adult influencers. Young people are further challenged by the harsh conditions in which they have to mature and grow. It is understandable that young people will participate and even embrace in the tensions that exist and hold the community together in seeking to identify with and belong in an environment that is hostile and rejecting of them as individuals. Clark (2011:15), in his context, identifies such an environment as one of abandonment, a 'systemic societal abandonment' by the adult community, leaving the youth to fend for themselves and create their own world and meaning (Noble-Carr \& Woodman 2016:4). The need for positive adult guidance remains a great need for the coloured adolescent living on the Cape Flats (cf. Black 1991:82-84; Gast, Okamoto \& Feldman 2017:116), as a coloured adolescent could easily be classified as one that is vulnerable because of the lived realities being defined by factors such as poverty, violence and chemical substance abuse (Noble-Carr \& Woodman 2016:4). At the same time, because of the heterogeneity of youth on the Cape Flats, not all young people will be susceptible to the threats and exposures of their community because of various support systems that may be in place (Williams \& Deutsch 2016:206).

\section{The identity formation of the young person}

In returning to the research problem of identity formation of coloured adolescents, one has to consider that identity formation is more than a process of being matured into adult roles (Cloete 2012:74; cf. Nel 2000:100). Identity formation, instead, is when the young person seeks answers to his or her questions, even the quest to construct the correct or appropriate existential questions to life (Cloete 2012:74; Erwin 2010:148). Furthermore, identity is comprised of 'beliefs, values and goals that the adolescent finds personally worthy and to which he or she is unquestionable committed' (Atkinson 1997:21). Cloete (2012:74) argues that a 'healthy identity formation needs a spiritual foundation'. In this sense, identity formation like faith formation shares similar pursuits in seeking answers to questions regarding life and its meaning. In this manner, while identity formation and faith formation are not synonymous, they, however, cannot be separated.

King (2007:231) acknowledges that many studies have reflected a positive effect that religion has on the identity formation of youth. Religion can, therefore, serve as a resource for PYD. King further reflects that later research is not conclusive on the relationship that religiosity has a positive influence on identity formation. It does, however, become apparent that further empirical research is required to examine the relationship between religiosity and youth identity formation, specifically when considering identity politics that involve race and ethnicity (Williams \& Deutsch 2016).

\section{Christian religiosity}

This article attempts to place the youth ministry in a specific epistemology, that of Christian religiosity. This section will attempt to define and contextualise Christian religiosity. Although there are many agencies that focus on youth and PYD, Christian youth ministry is often not included as an avenue for PYD. All beings are spiritual, whether one is able to acknowledge it or not, however, there is a distinction between spirituality and Christian spirituality (Cloete 2012:71). Christian spirituality and Christian spiritual formation, according to Cloete (2012:71), is 'a process through which human beings become more and more like Jesus in their way of living through the work of the Holy Spirit'. Christian spiritual formation, for Cloete (2012:72), is linked closely with faith formation, which is a holistic integration of everything that we believe and is expressed through a way of living. Faith formation, therefore, is a dynamic and continual process of cognition and experience as practised in the faith tradition and personal pursuit of knowing God.

\section{Defining religiosity}

Religion is important in most African communities and is no different on the Cape Flats. Religiosity, while covering a range of different understandings and definitions, is ultimately defined by the context in which it is used but is 'traditionally couched as an individual's level of spiritual commitment or religious affiliation' (Barnett, Bass \& Brown 1996:1163; cf. also McDaniel \& Burnett 1990:101). Religiosity, for McDaniel and Burnett (1990:103) is defined as 'a belief in God accompanied by a commitment to follow principles believed to be set forth by God'. Barnett et al. (1996:1163; cf. Cornwall et al. 1986:227) define religiosity in terms of cognition, affect and behaviour. Cognition involves a subscription to religious beliefs and behaviours. Affect has to do with the feeling or emotional attachment one has to a religious belief. Behaviour includes a wide variety of actions ranging from but not limited to church affiliation, disciplines in reading and studying the Bible and prayer. Religiosity is expressed in personal and institutional modes (Cornwall et al. 1986:227):

The personal mode is comprised of religious beliefs, feelings, and behaviors [sic] that find their source in personal and individualized religion. This includes the acceptance of doctrinal orthodoxy drawn from a broader cultural milieu (i.e. general Christianity as opposed to doctrines of a particular sect or denomination), feelings and commitment toward God, and religious behavior $[s i c]$ (personal prayer, giving to the poor, and encouraging others to believe in Christ). The institutional mode is comprised of the religious beliefs, feelings, or behaviors [sic] related to formalized [sic] and institutionalized [sic] religion. 
The institutional mode includes acceptance of religious beliefs which are unique to a sect or denomination, personal feelings and attachments to a particular church or congregation, and participation in religious ritual and worship services. (Cornwall et al. 1986:228)

Religiosity, therefore, in this context can be understood as faith formation as both personal and institutional. In the personal sphere, it is a belief in God that is expressed in a lifestyle that is associated with that set of beliefs. At the institutional level, it is everything that is included and practised as part of the faith tradition as expressed in the local church.

\section{The function of Christian religiosity}

Religiosity, therefore, can be understood and viewed as the faith formation in an individual. Faith formation, however, is not limited to an individual's effort alone. Faith formation, furthermore, is also attributed to the influences and effects of institutions and contexts on the individual and not solely to the individual's own efforts. It is not unusual to acknowledge that there are a direct influence and relationship between faith formation and one's environment (Erwin 2010:108). Faith formation, therefore, is an intentional, ongoing and dynamic process (Cloete 2012:71) on behalf of both the individual and their religious or faith community. Faith formation has been argued to generate trait and future hope, stability and resilience (Ciarrochi \& Heaven 2012:677-679). Faith formation could have a tremendous influence on the psychological development of the individual (Ciarrochi \& Heaven 2012:684).

\section{Positive youth development}

Noble-Carr and Woodman (2016:17) argue that positive identity development is more complex and challenging for vulnerable youths. PYD is more than an attempt to address the risky behaviour of vulnerable adolescents. PYD, usually through coordinated programmes, is also an attempt to promote positive behaviour, not only an attempt to address, and decrease, negative behaviour. Areas of focus usually include:

bonding, resilience, social, emotional, cognitive, behaviour or moral competence, self-determination, spirituality, self-efficacy, clear and positive identity, belief in the future, recognition for positive behaviour, opportunities for pro-social involvement and/or pro-social norms. (Bonell et al. 2016:2)

The religious beliefs of an individual have many positive effects on a person's behaviour (McDaniel \& Burnett 1990:103; Noble-Carr \& Woodman 2016:5). Religiosity or faith formation, according to Brittian et al. (2013:654), can be instrumental in PYD, as it constitutes a 'characteristic' of PYD. As a characteristic of PYD, religiosity 'promotes positive behaviors [sic]' (Brittian et al. 2013:654) and ultimately positive development of young people, specifically in the area of social control by refraining from involvement in risky behaviour. Brittian et al. (2013:649) further explains that religiosity is influential in five areas of the lives of the young people, namely it 'provides support, connection to the past, moral compass, promotes healthy development, and intersections between African traditional practices and Christian beliefs'. Religiosity, therefore, not only attempts to address negative issues but it also promotes positive behaviour by encouraging youth to refrain from risky behaviour (Brittian et al. 2013:654) in the midst of difficult circumstances.

Bonell et al. (2016:2) argue that it remains insufficient to evaluate the effectiveness of a PYD 'unless we are clear what theory of change this approach involves and whether particular interventions embody it'. The theory of change ${ }^{5}$ referred to in their study involves the causal and normative theories. It becomes critical in identifying the theory ${ }^{6}$ that the agency of youth ministry can be clustered with, the approach one utilises in youth ministry and the interventions one plans through the agency of youth ministry. It is, therefore, understandable that the approach and interventions employed will differ between various communities based on the needs of youth, whether actual or perceived, especially in a South African context.

Dames (2014:34) argues that a methodology for a South African context has to consider how cultural identity, community and context influence each other. Nel (2003:7576) similarly recognises the need for 'new practice theories' that will not only be relevant in a South African context but also birthed out of a South African context. The unfortunate part of this reality is that there is a deficit of resources from a South African context, in particular, resources that are informed through empirical research (Weber 2015:1-2).

\section{Youth ministry}

Youth ministry is a concept that has gained much attention since the Industrial Revolution and exists in its current form for the last century (Senter 2001:126). Youth ministry was a response to the ever-increasing gap that resulted between youth culture and the church. At first, the church was unable to make major inroads into youth culture and thus saw the formation of the parachurch youth organisations such as YMCA, Boy Scouts and YFC (Nel 2000:55). When the church eventually began its ministry for youth, it took on the shape of the parachurch youth organisations. This usually had a single charismatic leader leading and coordinating the youth ministry, with a special emphasis on evangelism through the sharing of the Gospel. When the youth ministry eventually became a part of the church, it began resembling an activities

5.Bonell et al. (2016) goes to great lengths to discuss and evaluate both the strengths and weaknesses of the theories of change attached to PYD, namely the normative theory and the causal theory. The normative theory is 'focused on the need to increase young people's assets and ability to thrive, by developing affective relationship with providers and engagement in a diverse range of activities offered by PYD programmes'. The causal theory considers how 'PYD programmes can promote positive development by instilling young people with an ability for intentional self-regulation'.

6.The author believes that assigning youth ministry to a particular theory is not a permathor believes that assigning youth ministry to a particular theory is not perman in the community. In addition wilo the nased of youth in the community. In addition to the needs of youth in the community, the theological perspective of the faith community should also be taken into consideration as it will ultimately influence the faith communities approach to youth ministry (cf. Nel 2000:63). 
club with a strong focus on programmes in an attempt to prevent these youths from going back into the world and keeping them from wandering the streets (Clark 2001:82-83). Youth ministry programmes would generally be grouped into evangelism and discipleship and were located in the educational ministry of the church (Clark 2001:82; Nel 2003:63). As time progressed, youth ministry eventually became recognised as a legitimate ministry of the church as well as a subdiscipline of practical theology, requiring specific theological understanding and praxis and no longer as a subsidiary of the educational ministry of the church (Jacober 2011:16; Nel 2000, 2003:68; Root \& Dean 2011).

\section{The agency of youth ministry}

Youth ministry could qualify as an agency of PYD. As a PYD, youth ministry has to acknowledge the 'plasticity of young people' (Silbereisen \& Lerner 2007:5). The 'plasticity of young people' is the ability or at least the potential, for young people to change and better themselves. Secondly, young people should be considered 'as resources to be developed, and not as problems to be managed' (Silbereisen \& Lerner 2007:5). Too often has youth ministry been focussed on an end goal, albeit a spiritual commitment and a faith walk with Jesus Christ, or a rehabilitated lifestyle, often at the expense of the dignity of the young person. Youth ministry in this sense serves as a 'developmental asset' as it creates an opportunity for the promotion of PYD and encourages youth's well-being (Silbereisen \& Lerner 2007:5). Furthermore, there has been agreement that religiosity has a positive overall influence in the lives of young people (King 2007:227; Silbereisen \& Lerner 2007:16). Areas that youth ministry may have particular influence in the lives of youth that are noteworthy are 'the development of civic engagement, moral excellence, and a sense of purpose in life' (Silbereisen \& Lerner 2007:16).

Silbereisen and Lerner (2007:16) reflect on King's study (2007) that a significant contribution to youth development is facilitated through the mediation of religious organisations by generating social capital. Social capital resources are identified as 'interactive, trustworthy, and mutual relationships with parents, friends, and adults' (Gast et al. 2017:97; King 2007:231). It becomes vital to recognise the need for adult leaders in the ministry to and with youth, which often seems contradictory in the youth peer-to-peer movement as is often observed in many youth ministries (Gast et al. 2017:116). Although attempting to argue for the need for an adequate theological articulation of the youth pastor (Aziz 2016), this article, however, raises the consideration of the youth pastor as social capital. It would be a worthwhile research to test whether the youth pastor does actually qualify as social capital and how it can be of service to youth in communities in tension.

In youth ministry, young people often ask difficult existential questions regarding life and the meaning of life in the midst of their struggles. It is during such enquiries where renewed praxis is required. One, however, cannot simply devise easy plans and programmes to remedy or attempt to transform a situation without dealing with historic underlying factors. The youth pastor, as social capital, through the agency of youth ministry, in its quest to assist the young person to have a deep and meaningful relationship with God (Aziz 2016:125), has to acknowledge that the spiritual is influenced and impacted by the context and situations young people have previously encountered and continue to encounter, experiences that are often traumatic. The focus in youth ministry cannot only be the spiritual formation of the young person, as is often the case, without the recognition of all that affects the young person. Any transformative youth ministry response as a PYD cannot be satisfied with the simplistic programmes that are void of any thought or reflection. Youth ministry praxis, as a practical theological discipline, ought to have an honest reflection on the lived realities of young people by reflecting on not only God's working in and through their circumstances but also God's desire to transform their circumstances. Youth ministry, in this sense, serves as a hermeneutical agency by interpreting the lived realities of young people in light of the divine. Yet, reflection is not the only task of youth ministry. Youth ministry as a practical theological praxis requires reflection and action, an action which should be seen as a participation in God's divine plan to make youth what he has already made them be (Nel 2000:101). In this sense, the role of the youth pastor as social capital in PYD should justifiably be considered.

\section{Recommendations}

The identity formation of young people is not an isolated and simple process. One has to consider the impact of the immediate environment or context, the historical context, as well as the spiritual formation of the young person as active agents in their identity formation. In order for youth ministry to be successful as an agent of PYD, it has to consider the far-reaching implications of simple methods employed with minimum reflection on the race, ethnicity, culture and environmental dynamics that influence the young person. Furthermore, the identity formation of the young person cannot be realised through a single programme employed by youth ministry but is an ongoing journey of reflection and action required of both the youth practitioner and young person.

The youth pastor should be considered as social capital who is able to serve in a significant way by being a guide, mentor and source for positive identity role model. In this sense, the youth pastor is able to generate trust between not only peers of youth but also significant adults (Gast et al. 2017:97). The youth pastor, through adequate theological reflections, is able to create environments where youth are free to be guided through their existential questions, in particular, their identity formation. Further research in a South African context can test the validity of the youth pastors as social capital, and how they are able to foster the embedded elements of social capital theory.

As a PYD, youth ministry in a community in tension is able to develop a theory of construct, namely the normative theory, by offering meaningful and effective relationships. As already 
argued, that the youth pastor serves as social capital, the person is able to develop further a community of significant adult members through an intentional intergenerational ministry in a South African context that would replace the destructive groups and practices and extend a welcome to the vulnerable youth.

\section{Conclusion}

As in any research, this article does recognise the need for further research on how youth ministry and religiosity can assist with PYD in both personal and institutional levels. What are the processes that should be in place or are currently in place that may assist with positive development in young people? How does one evaluate the efficacy of such programmes in line with the goals of being a PYD? How can the youth pastor, through an intentional intergenerational ministry, create significant and meaningful social capital that would be of value to vulnerable youth? These are not easy questions to answer considering the complexities of the lived realities of young people, which are then further compounded by the heterogeneity of youth. It thus further leads to the need for continuous empirical research in this area as there remains a deficit of theory and information, particularly in the above context.

\section{Acknowledgements}

\section{Competing interests}

The author declares that he has no financial or personal relationships which may have inappropriately influenced him in reviewing this article.

\section{References}

Adhikari, M., 2005, Not white enough, not black enough: Racial identity in the South African Coloured community, Double Story Books, Cape Town.

Adhikari, M., 2008, 'From narratives of miscegenation to post-modernist re-imagining: Toward a historiography of coloured identity in South Africa', African Historical Review 40(1), 77-100. https://doi.org/10.1080/17532520802249472

Adhikari, M., 2009, 'Predicaments of marginality: Cultural creativity and political adaption in southern Africa's coloured communities', in M. Adhikari (ed.) Burdened by race, pp. viii-xxxii, UCT Press, Cape Town.

Amoateng, A.Y. \& Richter, L., 2007, 'Social and economic contexts of families and households in South Africa', in T.B. Heaton \& A.Y. Amoateng (eds.), Families and households in post-apartheid South Africa: Socio demographic perspectives, pp. 1-26, HSRC Press, Cape Town.

Atkinson, H., 1997, Ministry with youth in crisis, Religious Press, Birmingham, AL.

Aziz, G., 2016, 'A practical theological reflection on the office of the career youth pastor', PhD thesis, Dept. of Practical Theology, University of Pretoria.

Barnett, T., Bass, K. \& Brown, G., 1996, 'Religiosity, ethical ideology, and intentions to report a peer's wrongdoing', Journal of Business Ethics 15, 1161-1174. https:// doi.org/10.1007/BF00412815

Bernardo, C., 2016, 'Why Wayde's gold is a win for the coloured identity', IOL, 15 August 2016, viewed 09 September 2016, from http://www.iol.co.za/news/whywaydes-gold-is-a-win-for-coloured-identity-2057061

Black, W., 1991, An introduction to youth ministry, Broadman Press, Nashville, TN.

Bonell, C., Hinds, K., Dickson, K., Thomas, J., Fletcher, A., Murphy, S. et al. 2016, 'What is positive youth development and how might it reduce substance use and violence? A systematic review and synthesis of theoretical literature', BMC Public Health 16, 135. https://doi.org/10.1186/s12889-016-2817-3

Bowers Du Toit, N.F., 2014, 'Gangsterism on the Cape Flats: A challenge to "engage the powers"', HTS Teologiese Studies/Theological Studies 70(3), Art. \#2727, 1-7. https://doi.org/10.4102/hts.v70i3.2727

Bray, R., Gooskens, I., Kahn, L., Moses, S. \& Seekings, J., 2012, Growing up in the New South Africa: Childhood and adolescence in post-apartheid Cape Town, HRSC Press, Cape Town.

Brittian, A.S., Lewin, N. \& Norris, S.A., 2013, "“You must know where you come from": South African youths' perceptions of religion in a time of social change', Journal of Adolescent Research 28, 642. https://doi.org/10.1177/0743558413480834
Calix, K.R., 2013, 'Wie is ek? Coloured identity and youth involvement in gangsterism in Cape Town, South Africa', Senior Honours thesis, Stanford University.

Ciarrochi, J. \& Heaven, P.C.L., 2012, 'Religious values and the development of trait hope and self-esteem in adolescents', in L.R. Olsen (ed.), Journal for the Scientific Study of Religion 51(4), 676-688. https://doi.org/10.1111/j.1468-5906.2012.01675.x

Clark, C., 2001, 'The missional approach to youth ministry', in M.H. Senter III (ed.), Four views of youth ministry and the church, pp. 77-96, Zondervan, Grand Rapids, MI.

Clark, C., 2011, Hurt 2.0: Inside the world of today's teenagers, Bakers, Grand Rapids, $\mathrm{MI}$.

Cloete, A., 2012, 'Spiritual formation as focus of youth ministry', G.V. Brand (ed.) Dutch Reformed Theological Journal [S.I.] 53(3-4), 70-77. https://doi. org/10.5952/53-3-4-250

Cornwall, P.H., Albrecht, S.L., Cunningham, P.H. \& Pitcher, B.L., 1986, 'The dimensions of religiosity: A conceptual model with an empirical test', Review of Religious Research 27(3), 226-244. https://doi.org/10.2307/3511418

Counted, V., 2016, 'Missionising youth identity crisis: Towards a missional hermeneutic of coping in youth ministry practice', Missionalia: Southern African Journal of Missiology [S.I.] 44(1), 85-102. https://doi.org/10.7832/44-1-141

Dames, G.E., 2008, 'Ethical leadership in and through the family, religious, secular traditions and the youth', NGTT 49, 3\&4, viewed 13 October 2016, from http://ojs. reformedjournals.co.za/index.php/ngtt/article/view/804/1203

Dames, G.E., 2014, A contextual transformative practical theology in South Africa, AcadSa, Parow, South Africa.

ENCA, 2016, 'Crime stats show Western Cape is SA's murder capital', Saturday 03 September 2016, viewed 04 September 2016, from http://www.enca.com/southafrica/crime-stats-reveal-western-cape-holds-most-murder-hotspots

Erwin, P., 2010, A critical approach to youth culture: Its influences and implications for ministry, Zondervan, Grand Rapids, MI.

Gast, M.J., Okamoto, D.G. \& Feldman, V., 2017, “"We Only Speak English Here”: English dominance in language diverse, immigrant after-school programs', Journal of Adolescent Research 32(1), 94-121. https://doi.org/10.1177/0743558416674562

IOL, 2015, 'Cape Town battles teen pregnancy', 24 May 2015, viewed 30 August 2016, from http://www.iol.co.za/news/south-africa/western-cape/cape-town-battlesteen-pregnancy-1862477

Jacober, A.E., 2011, The adolescent journey: An interdisciplinary approach to practical youth ministry, IVP Books, Downers Grove, IL.

King, P.E., 2007, 'Adolescent spirituality and positive youth development: A look at religion, social capital, and moral functioning', in R.K. Silbereisen \& R.M. Lerner (eds.), Approaches to positive youth development, pp. 227-242, Sage, London.

McDaniel, S.W. \& Burnett, J.J., 1990, 'Consumer religiosity and retail store evaluative criteria', Journal of the Academy of Marketing Science 18(2), 101-112. https://doi org/10.1007/BF02726426

McKaiser, E., 2012, 'Not white enough, not black enough', NY Times, 15 February 2012 viewed 09 September 2016, from http://latitude.blogs.nytimes.com/2012/02/15/ in-south-africa-after-apartheid-colored-community-is-the-big-loser/

Müller, J.C., 2004, 'HIV/AIDS, narrative practical theology, and postfoundationalism The emergence of a new story'. HTS Teologiese Studies/Theological Studies 60(1/2), 293-306. https://doi.org/10.4102/hts.v60i1/2.516

$\mathrm{Nel}, \mathrm{M} ., 2000$, Youth ministry: An inclusive congregational approach, Malan Nel, Pretoria.

Nel, M., 2003, 'Youth ministry as practical theology: Making a case for youth ministry as academic discipline', Journal of Youth and Theology 2(1), 68-83. https://doi. org/10.1163/24055093-90000205

Nel, M. \& Thesnaar, C., 2006, 'Theologically informed and culturally relevant youth ministry', Practical Theology in South Africa 21(2), 90-112.

Noble-Carr, D. \& Woodman, E., 2016, 'Considering identity and meaning constructions for vulnerable young people', Journal of Adolescent Research 1-27, viewed 11 November 2016, from http://www.sagepub.com/journals

Parker, M.B., Wills, G.B. \& Wills, J. 2008, Community in tension (CiT), Electronics and Computer Science, University of Southampton, Technical Report ECSTRLSL08-002, viewed 12 June 2016, from https://eprints.soton.ac.uk/266678/1/ ParkerWills_CiT.pdf

Republic of South Africa, 2008, National Youth Development Agency Act (NYDA), No54 2008, viewed 30 August 2013, from http://www.thepresidency.gov.za/docs/ nyda_act.pdf

Root, A. \& Dean, K.C., 2011, The theological turn in youth ministry, IVP, Downers Grove, IL.

Senter, M.H., 2001, 'The strategic approach to youth ministry', in M.H. Senter III (ed.), Four views of youth ministry and the church, pp. 113-135, Zondervan, Grand Rapids, MI.

Silbereisen, R.K. \& Lerner, R.M., 2007, 'Approaches to positive youth development: A view of the issues', in R.K. Silbereisen \& R.M. Lerner (eds.), Approaches to positive youth development, pp. 3-30, Sage, London.

Strong, P., 2014, 'Effective youth ministry: Embracing a family-orientated approach', Die Skriflig 48(1), Art. \#1715, 1-8. https://doi.org/10.4102/ids.v48i1.1715

Weber, S., 2015, 'A (South) African voice on youth ministry research: Powerful or powerless?', HTS Teologiese Studies/Theological Studies 71(2), Art. \#2973, 1-6. https://doi.org/10.4102/hts.v71i2.2973

Williams, J.L. \& Deutsch, N.L., 2016, 'Beyond between-group differences: Considering race, ethnicity, and culture in research on positive youth development programs' Applied Developmental Science 20(3), 203-213. https://doi.org/10.1080/108886 91.2015.1113880 